\section{Perspectives of the forest workers in Greece}

\section{Tsioras PA}

This study aims at examining the perspectives of the Greek forest workers and the benefits that will be derived from the introduction of a forest workers' training system. A postal questionnaire was distributed to 115 experts on forest operations nationwide, and personal interviews were conducted with 106 forest workers in 13 prefectures of Greece. The questionnaire was completed by 99 forestry experts with long experience on forestry issues all over Greece. The majority of the participants believed that there is a lack of interest on behalf of the State and that the most pressing problems are income-related. The results indicate that the number of forest workers will continue to decline unless specific measures are taken. Changes in the forest management systems are necessary since the present status has not lived up to the expectations. The introduction of a forest workers' training system is expected to bring professionalism to the sector of forest operations, increase the overall productivity and improve the perspectives of the forestry workforce in Greece.

Keywords: Forest workers' training system, Greece, Forest operations, Certification of vocational qualifications, Work perspectives

\section{Introduction}

Forest operations are among the most arduous and hazardous professions in all fields of production (Poschen 1993). Productivity, efficiency, health and safety in forest operations need a well trained and motivated workforce, which is a prerequisite for the implementation of the multiple aspects of sustainable forest management.

It is estimated that in all subsectors of forestry, about 10 million people are employed worldwide (FAO 2010). Official data shows a major decrease in the number of forest workers in many European countries (Jacob et al. 1994, Gröger \& Lewark 2002 BUS/BUWAL 2003). According to Salminen et al. (1999), the numbers of Finnish forest workers dropped by $50 \%$ in the period 1990-1995 as a result of increased mechanization. In Sweden, the number of the forest workers has dropped by $90 \%$, from 100000 to 10000 during the last 40 years for the same reason (Axelsson 1998).

Employment in the primary sector in the years 1998-2009 declined by $42.3 \%$ from $17.5 \%$ to $12.3 \%$ in Greece (National Statist-

Laboratory of Forest Utilization (POB 227), Faculty of Forestry and Natural Environment, Aristotle University of Thessaloniki,GR-54124 Thessaloniki (Greece)

@ Petros A. Tsorias (ptsioras@for.auth.gr)

Received: Apr 13, 2010 - Accepted: May 28, 2010

Citation: Tsioras PA, 2010. Perspectives of the forest workers in Greece. iForest 3: 118123 [online: 2010-09-27] URL:

http://www.sisef.it/iforest/show.php? id $=547$ ical Service of Greece 2010), following the international trend which has been described as inevitable (OECD 2000). Official data shows a steady decline in the number of forest workers in Greece (Fig. 1). However, the exact size of the forestry workforce can not be estimated from the official data due to the unknown number of the inactive members of the forest cooperatives (Sakkas 1980, Tsioras 2004).

An annual decline of $2.03 \%$ in the number of forest workers took place during the 19611971 decade, which resulted in increased difficulties in the management of Greek forests, especially with regard to the volume of silvicultural and harvesting operations (Sakkas 1980). Changing the forest exploitation system was considered to be the solution to this problem. The new legislation (Presidential Decree 126/1986) provided many privileges to the forest workers' cooperatives, by recognizing them almost as the exclusive works undertaking system in the framework of wood harvesting and utilization processes of the public forests. The new legislation aimed at the facilitation of forest utilization in Greece through the redistribution of income from the forests in favour of the forest

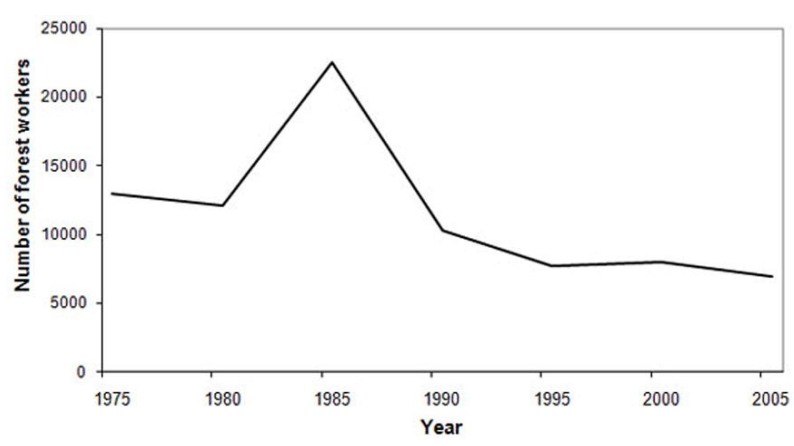
Greece. workers' cooperatives (Karameris 1987).

However, this legislation, which is currently active, has not lived up to the expectations due to the inability of the forest cooperatives to cope with their demanding tasks and the lack of proper control by the forest authorities. The lack of vocational training is responsible for the lack of professionalism, cooperative spirit and low quality of Greek forest operations, as most of the forest workers rely on their on-the-job experience (Tsioras 2004). Many forest cooperatives have been driven to extinction and internal problems have led to split-ups in the cooperatives resulting in the establishment of new ones. A paradox prevails in Greek forest operations: in some regions the workforce is not enough to challenge forest exploitation, whereas in other areas large numbers of forest cooperatives turn forest exploitation into a problem (Tsioras 2004).

This study was conducted in order to explore the following issues in relation to forestry workforce in Greece:

- Identify current problems of the forest operations sector with special regard to forest workers' cooperatives.

- Assess forest policy instruments as a means to increase the attractiveness of forestry professions.

- Investigate the perceptions on the introduction of a forest workers' training system.

- Make suggestions that may improve the perspectives of the forestry workforce in

\section{Materials and methods}

In order to improve the knowledge and understanding of the prevailing situation of the forestry personnel in Greece detailed and accurate information was required. Therefore, the attitudes of the people involved in all aspects of forest operations (management, education, research and execution of the forest operations) were investigated and compared in order to draw up recommendations for the future of the sector.

\section{Selection of participants}

The comparison of perceptions of forestry experts and forest workers was chosen as a means to explore forestry personnel per-

Fig. 1 - Changes in the employment of the Greek forest operations sector in the period 1975-2005 (Blombäck et al. 2003, Sakkas 1980). 
spectives in Greece. The selection of forestry experts was done following the "experts sampling method", a type of purposive sampling. Purposive or judgemental sampling is suggested, when the researchers are convinced that a subset of the population, can provide more precise information, due to extensive experience of its members on the study objectives (Siardos 1997, Babbie 2009). Therefore, a list of all experts on forest operations was compiled, consisting of university professors, researchers, representatives of the private forest owners' union and experienced officers of the State Forest Service.

The selection of forest workers proved to be more difficult, because the official data did not provide up-to-date data on the active members of the forest workers' cooperatives. As a result of this, detailed information about the forest workers' cooperatives was not accurate, especially with regard to the exact number of their active members Therefore, despite the increased costs entailed, it was decided that all study areas should be visited and that the situation would be examined on site. This data collection method was justified by our findings, since some cooperatives with an especially strong presence in the past, had only few remaining members. It should also be noted that the choice of the study areas was done in such way to ensure the sample representativeness with respect to the geographic distribution of forest workers' cooperatives in Northern, Western and Central Greece, where the majority of forest operations take place in Greece.

Furthermore, certain selection criteria were decided, in order to ensure that the study participants should fit, as close as possible, the profile of the full-time forest worker. Therefore the forest workers who would be chosen to participate should: a) be members of a forest workers' cooperative, active in the study areas for at least three years and b) work and live in the area of the forest workers' cooperative. The number of participants was estimated according to proportionate stratified sampling. The work experience of the forest workers was used as stratification criterion (1-10 years, 11-20 years, 20-30 years and more than 30 years)

\section{Questionnaire and interviews}

The results in this article stem from a questionnaire mailed to forest operations experts nationwide and personal interviews held with forest workers in 13 prefectures in Greece during the period October 2003 January 2004. Data collection was based on a structured questionnaire with the majority of questions common for both participant groups. A set of different questions was also added, in order to explore the perceptions of each group in special aspects of the study.
The questionnaire consisted of six pages and was accompanied by a covering letter explaining the background and purpose of the study. In its first part, profile information was collected from all respondents. Its second part included questions on the current situation of forest operations, while its third part focused on the assessment of measures and incentives for the promotion of forest operations, as well as on the perspectives of the forest workers in Greece. A five-point Likert scale was used to measure the perceived level of importance (ascending scale from 1 to 5).

The questionnaire was initially designed based on the available literature and discussions with forest cooperatives' members, State Forest Service officers and university professors. The questionnaire was pre-tested with forestry experts and forest workers to check for biased, misleading, or confusing questions and to verify the quality and comprehensiveness of the retrieved information. A detailed description of the questionnaire, including the organization and format of individual questions is presented in the doctorate (thesis) of $\mathrm{P}$. Tsioras (Tsioras 2004).

Personal interviews were conducted for the data collection from the forest workers' cooperatives. During the interview procedure, most of the forest workers had a negative attitude towards this study, expressing their doubts on the contribution of this study. As a result of this, if the questionnaires had been sent by post, a very small return rate would have been expected. Furthermore, low literacy level represented another problem suggesting the use of personal interviews as the best way for data collection. Finally, informal follow-up discussions were provoked in order to assure the validity of the findings.

\section{Statistical analysis}

The responses were analyzed with the software SPSS Version 12. As the criteria of normal distribution and homogeneous variance of data were not met, solely nonparametric analyses were used to explore comparisons between respondents' subgroups and the relationships between variables. Because the responses were ratings, rather than a continuous measure, these data are not suitable for analysis of variance (SPSS 1998). The non-parametric alternative to a repeated measures analysis of variance is the Friedman test. The scores for each variable are ranked and the mean ranks for the variables are compared. Furthermore, the Friedman test is used to determine whether the differences between these ranks are statistically significant.

Maximum likelihood's $\chi^{2}$ test $(\alpha \leq 0.05$ and $\alpha \leq 0.1$ ) was also used to test whether statistically significant differences could be found between the answers of the two groups of participants.

\section{Results}

A total of 115 questionnaires were posted to forestry experts, of which $101(87.8 \%)$ were returned. Two of the returned questionnaires had to be excluded from further analysis because they were not completed. The high return rate of completed questionnaires $(86.1 \%)$ may be attributed to the interest of the respondents. Additionally, 106 forest workers were interviewed. Results are presented as numbers of respondents and interviewed forest workers, followed by the percentage values in brackets. It should be noted that, as not all questions were answered by all the respondents, the total sample (n) for each question varied and is therefore included with the results for each question.

\section{Background information concerning the participants}

The majority of the forestry experts were public officers $(50 \%)$, university professors $(30 \%)$ and researchers $(7 \%$ - Tab. 1). They had an average professional experience of $23.47 \pm 8.76$ years (standard deviation) and $42 \%$ of them had acquired a Doctorate in Forestry.

On the other hand, $21 \%$ of the forest workers interviewed were presidents of forest workers' cooperatives. The average age was $44.4 \pm 11.04$ years with a professional experience average of $22.61 \pm 10.55$ years. The large majority of them $(66 \%)$ has attended primary education (sometimes incomplete) and only $22 \%$ has attended secondary education. About $61 \%$ of the forest workers has attended short courses on forest operations issues held by the Forest Service.

\section{Current situation of forest operations in Greece}

All study participants were asked to assess the level of state interest, as perceived by them, in the forest operations sector. Three equal groups of forestry experts can be distinguished, which assessed the state interest from "very small" to "medium". The forest workers were more pessimistic, as $77.4 \%$ of them assessed it as "very small" (Fig. 2).

According to the forestry experts $78.9 \% \pm$ 25.4 of the forest operations in their prefecture is conducted by forest workers of each area. The quality of forest operations can be described as poor, since it was given a grade assessment of $54.6 \% \pm 20.4$. The most common problems during cooperation with forest workers were the bad quality of forest operations $(69.9 \%)$ and lack of professionalism (55.9\%). High accident rate represented a problem for only $21.5 \%$ of the forestry workers, despite their frequent involvement in accidents, which was revealed in the follow-up conversations.

The study participants were asked to assess the need for some forest professions in the 
future. The proposed forest professions included those of the: i) forest worker with the typical job content of a motor-manual worker in silvicultural and harvesting operations, ii) supervisor of forest operations, iii) forest tractor operator, iv) forest machine (harvester, forwarder and cable yarder) operator, and v) special worker, who could be employed in construction works in the forest, such as the construction of small water dams and torrent control works. The large majority of the forestry experts believed that there will be a need for forest workers $(85.54 \%)$ and forest machine operators $(60.8 \%)$ in the future (Tab. 2). On the other hand, forest workers were more optimistic with regard to the need for all the above mentioned professions in the future.

According to the majority of the respondents $(66 \%)$, the young people in the study areas did not wish to work in forest professions. Instead, they were more willing to search for other career opportunities in big cities. Employment in forestry is often the result of family pressure upon its younger members who are not willing to continue their studies in the tertiary education. Nevertheless, young people who had unsuccessfully tried to find a job in a bigger city, have returned to their communities to work in forest operations.

\section{Measures for promoting employment in forestry}

Incentives represented the best option in both groups of respondents, as a means of improving the attractiveness of the forest professions. Better promotion of the forestry sector through the vocational guidance system followed with $44.4 \%$ and $43.4 \%$ respectively (Tab. 3).

Both groups were asked to assess the importance of various types of incentives (Tab. $4)$. Forestry experts ranked incentive payments first, followed by equipment subsidies and earlier retirement $\left(\mathrm{F}_{[1,3]}=45.936\right.$, $\mathrm{p}<0.0001)$. However, equipment subsidies and earlier retirement were more important to the forest workers $\left(\mathrm{F}_{[1,3]}=79.316\right.$, $\mathrm{p}<0.001)$. Reduced taxation was not regarded as an important incentive because it was already low.

Both forestry experts and forest workers believed that the existence of a well organized occupation of the professional forestry worker could contribute to the keeping of the young people in rural mountainous areas. The help is depicted in the answers "very high" and "high" which summed up to $90.91 \%$ of the forestry experts' and $91.51 \%$ of the forest workers' answers $\left(\chi^{2}{ }_{2]}=7.44\right.$, $\mathrm{p}=0.024)$.

Contribution of a forest workers' training system (FWTS) to Greek forestry

Both forestry experts and forest workers

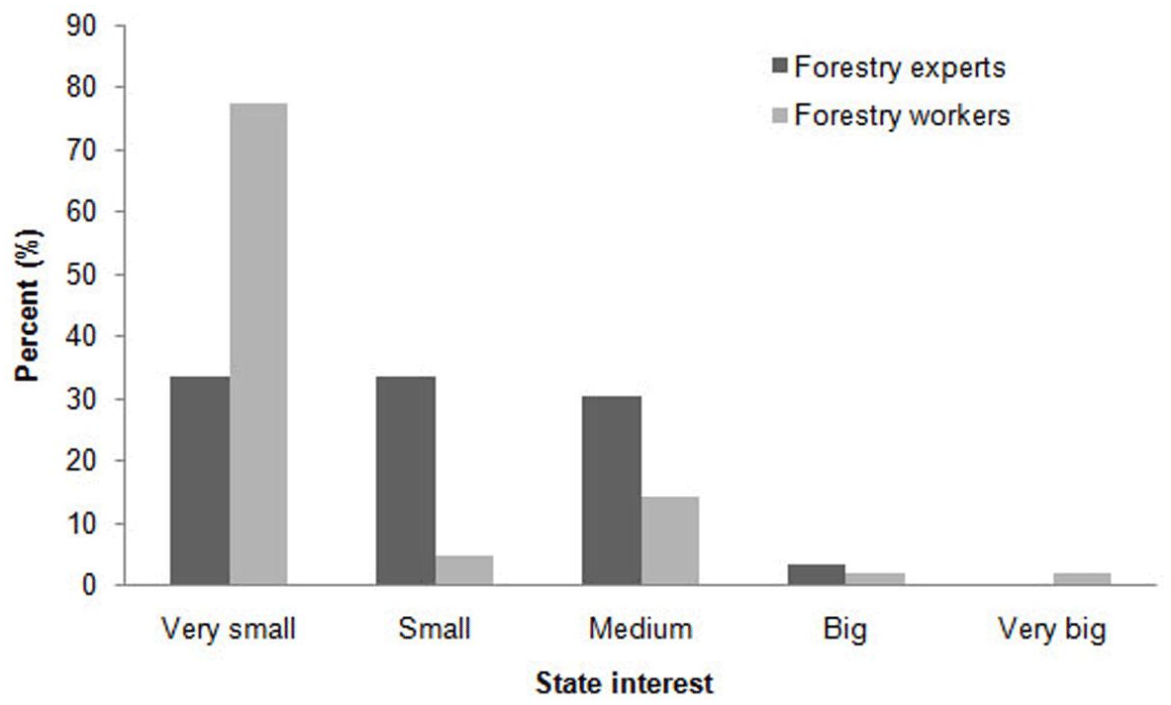

Fig. 2 - Assessment of the State interest by the participants in the study.

seemed convinced that contribution of a Greek forestry sector.

FWTS would be "very important" $\left(\chi^{2}{ }_{[2]}=\right.$ Trained forest workers are expected to $1.22, \mathrm{p}=0.543,66.7 \%$ and $69.81 \%$, respec- have better career opportunities as members tively) and "important" (28.28\% and $22.64 \%$ of forest cooperatives and as forest contracrespectively) to Greek forestry (Fig. 3). The tors according to the forestry experts (Tab. 5 need for the introduction of a vocational $\left.-\mathrm{F}_{[1,2]}=37.7, \mathrm{p}<0.0001\right)$. Forest workers training system was recognized as a means ranked first the perspectives of being memof improving the overall efficiency of the bers of forest cooperatives, followed shortly

Tab. 1 - Job description of the forestry experts $(n=99)$.

\begin{tabular}{lc}
\hline \multicolumn{1}{c}{ Type of job } & $\begin{array}{c}\text { Number (and percent) } \\
\text { of responses }\end{array}$ \\
\hline Forest engineer working as forest contractor & $10(10.1 \%)$ \\
Forest Service forest engineer & $52(52.5 \%)$ \\
University professor & $20(20.2 \%)$ \\
Technological Educational Institute professor & $10(10.1 \%)$ \\
Researcher & $7(7.1 \%)$ \\
\hline
\end{tabular}

Tab. 2 - Assessment of future need for forest professions in Greece. (**): level of significance $5 \% ;(*)$ : level of significance $1 \%$.

\begin{tabular}{lccccc}
\hline \multirow{1}{*}{ Profession } & \multicolumn{5}{c}{ Forest profession } \\
\cline { 2 - 6 } & $\begin{array}{c}\text { Forestry } \\
\text { workers } \\
\mathbf{n ~ ( \% )}\end{array}$ & $\begin{array}{c}\text { Supervisors } \\
\mathbf{n ~ ( \% )}\end{array}$ & $\begin{array}{c}\text { Forest tractor } \\
\text { operators } \\
\mathbf{n ~ ( \% )}\end{array}$ & $\begin{array}{c}\text { Forest machine } \\
\text { operators } \\
\mathbf{n ~ ( \% )}\end{array}$ & $\begin{array}{c}\text { Special } \\
\text { workers } \\
\mathbf{n}(\%)\end{array}$ \\
\hline $\begin{array}{l}\text { Forestry experts } \\
(\mathrm{n}=97)\end{array}$ & 82 & $33^{* *}$ & $33 * *$ & $59 *$ & $35 * *$ \\
Forest workers & $(84.5 \%)$ & $(34 \%)$ & $(34 \%)$ & $(60.8 \%)$ & $(36.1 \%)$ \\
$(\mathrm{n}=106)$ & 78 & $65 * *$ & $78 * *$ & $75 *$ & $69 * *$ \\
\hline
\end{tabular}

Tab. 3 - Measures to increase the attractiveness of the forest professions. $\left({ }^{*}\right)$ : level of significance $5 \%$

\begin{tabular}{lcc}
\hline \multicolumn{1}{c}{ Measure } & $\begin{array}{c}\text { Forestry experts } \\
(\mathbf{n = 9 9 )}\end{array}$ & $\begin{array}{c}\text { Forest workers } \\
(\mathbf{n}=\mathbf{1 0 6})\end{array}$ \\
\hline Incentives & $92(92.9 \%)$ & $104(98.1 \%)$ \\
Vocational guidance & $44(44.4 \%)$ & $46(43.4 \%)$ \\
Mass media & $22 *(22.2 \%)$ & $46 *(43.4 \%)$ \\
\hline
\end{tabular}




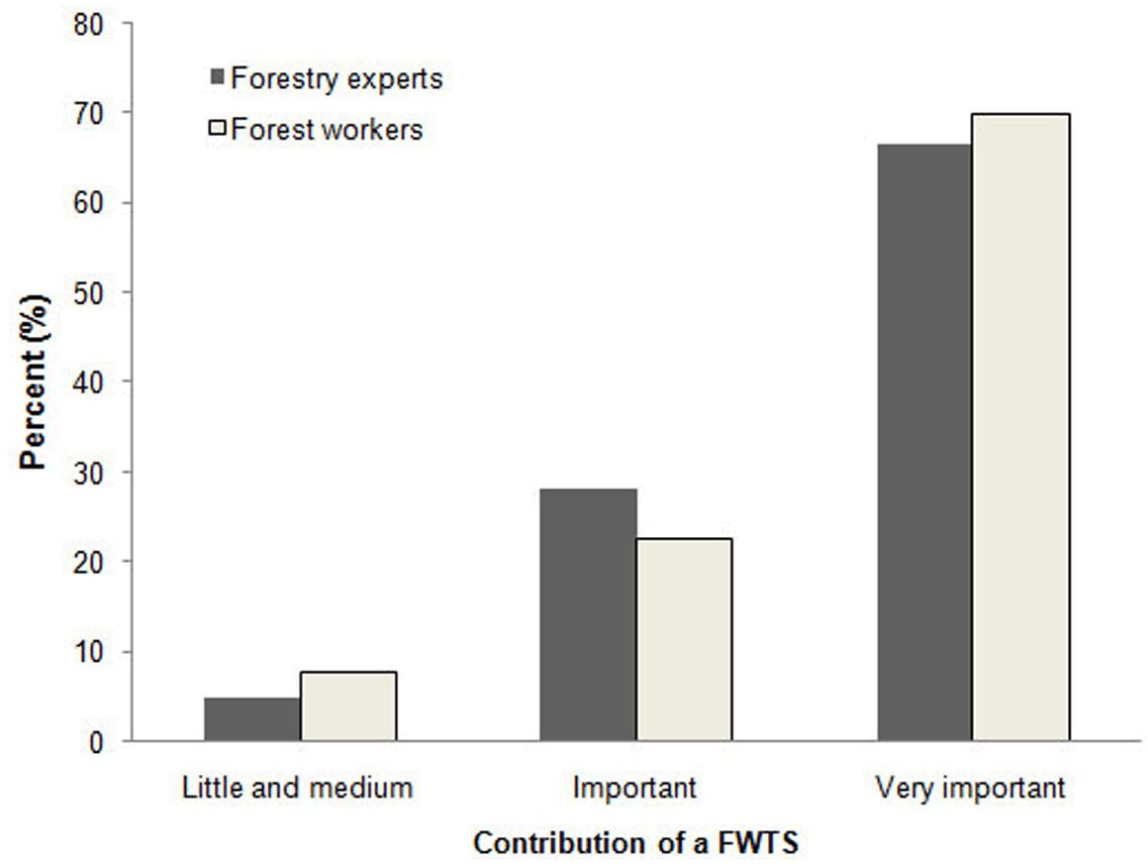

Fig. 3 - Future contribution of a FWTS to Greek forestry.

Tab. 4 - Respondents' perception of importance of various types of incentives (ranking according to Friedman test).

\begin{tabular}{lcc}
\hline \multirow{2}{*}{\multicolumn{1}{c}{ Incentive }} & \multicolumn{2}{c}{ Rank mean } \\
\cline { 2 - 3 } & Forestry experts & Forest workers \\
\hline Incentive payments & 3.01 & 2.60 \\
Equipment subsidies & 2.60 & 2.78 \\
Earlier retirement & 2.45 & 2.73 \\
Reduced taxation & 1.95 & 1.88 \\
\hline
\end{tabular}

Tab. 5 - Work perspectives' assessment of the trained forest workers (ranking according to Friedman test).

\begin{tabular}{lcc}
\hline \multirow{2}{*}{\multicolumn{1}{c}{ Work Perspective }} & \multicolumn{2}{c}{ Rank mean } \\
\cline { 2 - 3 } & Forestry experts & Forest workers \\
\hline Forest cooperatives members & 3.44 & 3.23 \\
Forest contractors & 2.96 & 2.70 \\
Employed by the Forest Service & 2.60 & 3.08 \\
\hline
\end{tabular}

by "employed by the Forest Service" $\left(\mathrm{F}_{[1,2]}=\right.$ $22.816, \mathrm{p}<0.0001)$.

\section{Discussion}

The overall analysis of the results indicates important findings regarding the forest operations in Greece. Different perceptions and attitudes are depicted in the answers of the respondents and basic guidelines for future changes can be drawn.

State interest on forest operations is assessed as "medium" to "very low", by the forestry experts and the majority of the forest workers $(77.4 \%)$ assess it as "very low". the quantity of the programmed forest operations per prefecture. In some cases, forest workers' cooperatives travel and work in prefectures close to their own, but when this is option is not available, the volume of silvicultural and harvesting works is negatively affected. This deficit underlines the need for a greater forest workforce, which will be sufficient to carry out the annual forest management plans. According to Blombäck et al. (2003) the trend is positive for well-trained forest workers under stable employment conditions and negative for poorly trained and equipped occasional wood-cutters, such as farmers. The large majority of respondents is convinced that there will be a need for forest workers in the future. However, forestry experts believe that trained forest workers and forest machine operators will be mainly asked for, whereas forest workers give high ratings to all five proposed professions. The professions proposed by the experts can be currently found in the Greek forests but are not accompanied by any professional training or licensing system. On the other side, the three other professions (forest tractor operator, supervisor of forest operations and special worker) are up to date, non-existent in Greek forest operations but proposed in the context of the study, as part of re-organization of the forest operations sector. The high ratings they received can be attributed to the wish of the forest workers for more and, possibly, better career opportunities.

Despite all political efforts, urbanization, though in smaller scale than in the past, still continues in Greece and mountain areas are currently populated by only $14.19 \%$ of the population (National Statistical Service of Greece 2010). Forestry professions traditionally functioned as the major source of income for the mountainous populations but the situation has changed during the last years. Socio-economical reasons are mainly responsible for this change, such as the declining income and attractiveness of the forest professions. However, Slee \& Wiersum (2001) note that forestry can contribute towards rural development by either improving or innovating production processes, or by providing an ecological infrastructure for an attractive rural landscape. Therefore, it is imperative to maintain the existing number of forest workers, considering the fact that timber-related employment exerts a powerful multiplier effect (Theophile 1996). Efthymiou (2001) has estimated that a work volume of 12 hours per hectare of forest area in Greece could provide employment to 50 000-52 000 professional forest workers, who would be working 200 days per year. This could imply a significant increase of rural employment in this mountainous country.

Forest professions suffer from reduced ability to attract new workers (Egan \& Tag- 
gart 2009). The job of the forestry worker in Greece is done mainly by middle-aged people, since the young people seek for other career opportunities in bigger towns. Convincing the younger part of the population to become involved in forest operations is of primary importance because no rural development can be achieved with a steadily ageing and declining population (Roca 1998). If the current trend does not change, there will be serious implications for the forest operations, by a further widening of the gap between the requested and the existing size of forest workforce.

Cubbage et al. (2007) describes a number of policy instruments that aim at the enhancement of multi-functional forest management. Some of these incentives can be used in increasing the attractiveness of forest professions. In the context of the study, the adoption of incentive payments prevails among all other proposed incentives in the opinions of forestry experts. The development of a well adjusted payment system is recognized as precondition for recruitment of forest personnel, while it is also connected with decreased accident rates and lower frequency of work-related illnesses (Toupin et al. 2006).

Some respondents also identify the need for increased equipment subsidies, especially by the forest workers who rank them first, among all other proposed incentives. Replacement of the current equipment was frequently mentioned by the interviewed forest workers and is perceived as a major problem. However, increasing equipment subsidies for unskilled workforce is a serious financial commitment with uncertain productivity outcome. For example, the replacement of an older chainsaw with a newer one, heavier and more powerful chainsaw is regarded as an equipment upgrade, although it entails ergonomical drawbacks and increased stress and fatigue for the operator (Parker et al. 1999). Especially in the case of expensive equipment, such as skidders or forest tractors, use by untrained personnel can be dangerous. The introduction of specific criteria for equipment replacement is necessary; these criteria will ensure the best possible choice and utilization of the new equipment, thus securing the investment cost.

Occupational illnesses and musculoskeletal symptoms are very common among Greek forest workers (Gallis 2006). Pain in upper extremities, back and neck, along with vibration-induced white finger, reduce the work capacity of the forest workers and could affect their income (Koskimies et al. 1992, Fenner 1997). Most accidents occur in wood harvesting and are characterized by severity, resulting in large amounts of lost productive work, besides other human, social and economic consequences of this tremendous loss (Efthymiou 1990). In this context, earlier re- tirement could also be used in order to increase the attractiveness of forestry professions and would be welcomed by the forest workers, according to their rankings. On the contrary, further reduction of the taxation would fail as an incentive, since it is already regarded as low.

The quality of forest operations is assessed by the forestry experts as poor, leaving space for considerable improvement. This is to be expected because most of the Greek forest workers do not have certified qualifications but rather rely on their on the work experience. Such knowledge may be unsystematic and haphazard, but can be supplemented through systematic adult training (Vik 1999). Today, vocational training is regarded as a basic precondition for every modern forestry. A very important finding of this study is that more than $90 \%$ of the study participants perceive the introduction of a forest workers' training system (FWTS) as very important for the Greek forest operations sector.

Vocational guidance is an important issue in improving labour performance and human resources development (ILO 2007). Surprisingly enough, less than half of the participants to the survey believe that promotion of the forest professions will be facilitated through the vocational guidance system. This is attributed, to a large extend, to the fact that Greek parents believe that the educational system fails, in terms of preparation of their children for entry into an appropriate profession (Saiti \& Mitrosili 2005).

Changes must also take place at legislation level. The introduction of new institutions, such as that of the licensed forestry worker, along with stricter control of the forest workers cooperatives, are necessary measures for the re-establishment of the institution of the forest cooperative, the main actor in forest operations in Greece. Karameris (1981) proposed the disqualification of inactive forest workers from their cooperatives as a means of rationalization of the forest operations. Furthermore, stricter control can avert forest contractors from employing economic immigrants as forest workers who don't belong to a certain forest cooperative. As long as the present situation remains unchanged the perspectives for the Greek forest workers will remain poor.

Lack of training however affects multiple aspects of the forest operations. Vocational training is much more than knowledge acquisition and development of professional dexterities; it is a means towards increasing the confidence of the forest workers and developing the sense of belonging to a larger group of people with similar professional abilities and expectations. Attending a special training course establishes another level of professionalism, a field where problems are also identified by $55.9 \%$ of the forestry experts. Today, lack of professionalism can easily be identified, as the majority of the forest cooperatives is not well organized and refuse the undertaking of thinning operations (Efthymiou 1992). In addition, lack of information on new trends, equipment and developments further worsen the situation. Inefficiencies in terms of organisation and management of forest cooperatives could be mainly attributed to the lack of vocational training (Tsioras 2004).

The disqualification of forest workers who fail to certify their vocational qualifications will facilitate improvements in terms of productivity, quality of work and occupational safety and health. The interviewees were very positive to such a development, regarding it as a means to safeguard their profession.

The job perspectives of the trained forest workers are expected to be better in the coming years than they are today. Some of the interviewed forest workers would prefer working for the Forestry Service at close proximity to their communities. This reflects their wish for a steady income, especially today when their income is declining, but under better conditions with regard to working hours and social benefits. It is also evident of their attachment to a place and a rural way of living, which is a critical factor in decision making concerning their professional life (Carroll et al. 2000). At this point, employment by the Forest Service represents the best working and wage conditions in the forest sector, combining steady income and social benefits. However, forest cooperatives' members are expected to have the best professional perspectives in the future.

\section{Conclusions}

The future of the forest workforce in Greece will be difficult, unless specific measures are taken. The findings clearly underline the need for introduction of a FWTS adapted to the special attributes of the Greek forestry and the current forest workforce. There is considerable divergence between the perceptions of forestry experts and forest workers, which derives from the level of education and experience. The current legislation is combined with negative developments in the management and utilization of Greek forests (Efthymiou \& Karambatzakis 1992). There is urgent need for a well trained certified forest workforce which can successfully cope with the needs and requirements of a modern, sustainable forestry of multiple functions. In this context, the use of incentives is necessary in order to sustain the current workforce and attract young people to the forest professions. The combination of new legislation, certification of vocational qualifications and real professionalism on behalf of the forest cooperatives can guarantee better job perspectives for the Greek forest workers. 


\section{Acknowledgements}

The author wishes to thank Prof. Dr. Paul. N. Efthymiou, as well as the journal referees for their thoughtful comments and recommendations. Mr. Andreas Sophiadis is thanked for editing the text and improving the English in the manuscript. Finally, I would also like to thank the forestry experts and forest workers who participated in this study.

\section{References}

Axelsson SA (1998). The mechanisation of $\log$ ging operations in Sweden and its effect on occupational safety and health. International Journal of Forest Engineering 9: 25-31.

Babbie ER (2009). The practice of social research (12 $2^{\text {th }}$ edn). Wadsworth Publishing, Belmont, CA, USA, pp. 530.

Blombäck P, Poschen P, Lövgren M (2003). Employment trends and prospects in the european forest sector, Geneva timber and forest discussion paper ECE/TIM/DP/29, United Nations, Geneva, Switzerland.

BUS/BUWAL (2003). Wald und Holz - Jahrbuch. Bundesamt für Statistik/BUWAL, Eidg. Forstdirektion.

Carroll MS, Daniels SE, Kusel J (2000). Employment and displacement among Northwestern forest products workers. Society and Natural Resources 13: 151-156.

Cubbage F, Harou P, Sills E (2007). Policy tools to enhance multi-functional forest management. Forest Policy and Economics 9: 833-851. - doi: 10.1016/j.forpol.2006.03.010

Efthymiou PN (1990). Situation of occupational safety in forest operations of Greece. In: Proceedings of the "European seminar on occupational safety in forestry", Munich (Germany) 5-6 July 1990.

Efthymiou PN (1992). National status report of Greece. In: "Final report of the concerted action: rationalization of harvesting operations" (Kofman PD ed). Danish Forest and Landscape Research Institute, Lyngby, Denmark, pp. 83-96.

Efthymiou PN, Karambatzakis T (1992). Evaluation of the wood harvesting and trade system by the forest workers' cooperatives with the Presidential Decree 126/86. In: Proceedings of the Fifth "Panhellenic conference of the Hellenic forestry society", Kalamata (Greece) 4-6 March 1992. Hellenic Forestry Society, Thessaloniki, pp. 262-270. (In Greek).

Efthymiou PN (2001). Forest protection and forest work. In: Proceedings of the scientific workshop "Forest growth and protection - Forest work" (Konstantinidis PN ed). Thessaloniki (Greece) 01
Feb. 2001. Ministry of Agriculture and FRI-NAGREF, Athens, Greece, pp. 57-71

Egan A, Taggart D (2009). Public perception of the logging profession in Maine and implications for logger recruitment. Northern Journal of Applied Forestry 26: 93-98.

FAO (2010). Global Forest Resources Assessment 2010 - Key findings. [online] URL: http://foris.fao.org/static/data/fra2010/KeyFindings-en.pdf

Fenner P (1997). Job accidents in a Brazilian forest company. In: Proceedings of the seminar "Safety and health in forestry are feasible!" (Blombäck P, Ris T, Jost D, Büchel M, Raemy O eds). Konolfingen (Switzerland) 6-11 Oct 1996. Swiss federal office of environment, forests and landscape, Berne, Switzerland, pp. 173-181.

Gallis C (2006). Work-related prevalence of musculoskeletal symptoms among Greek forest workers. International Journal of Industrial Ergonomics 36: 731-736. - doi: 10.1016/j.ergon.2006. 05.007

Gröger V, Lewark S (2002). Der arbeitende Mensch im Wald - eine ständige Herausforderung für die arbeitswissenschaft. Schriftenreihe der Bundesanstalt für Arbeitsschutz und Arbeitsmedizin Dortmund/Berlin/Dresden, Germany, pp. 174.

Jacob J, Huber M, Wirz R, Huerle PR, Lewark S (1994). Warum wechseln waldarbeiter ihren Beruf? Allgemeine Forst und Jagdzeitung 165: 16.

ILO (2007). Human resources development recommendation, 1975. International Labour Organization, UN. [online] URL: http://www.ilo. org/public/english/employment/skills/hrdr/instr/ r $150 . \mathrm{htm}$

Karameris A (1981). The socio-economical position of the forest cooperatives in mountainous areas of west Thessaly. Scientific Annals of the Department of Forestry and Natural Environment 24: 95-136. (In Greek)

Karameris A (1987). The impacts of the state forests' timber on the financial results of forest cooperatives: a case study in the prefecture of Trikala. Scientific Annals of the Department of Forestry and Natural Environment 30: 21-57. (In Greek)

Koskimies K, Pyykko I, Starck J, Inaba R (1992). Vibration syndrome among finnish forest workers between 1972 and 1990. International Archives of Occupational and Environmental Health 64: 251-256. - doi: 10.1007/BF00378282 National Statistical Service of Greece (2010). Employment report. [online] URL: http://www.statistics.gr/portal/page/portal/ESYE

OECD (2000). Employment outlook. Paris, France.
Parker R, Sullman M, Kirk P, Ford D (1999). Chainsaw size for delimbing. Ergonomics 42: 897-903. - doi: 10.1080/001401399185199

Poschen P (1993). Forestry, a safe and healthy profession? Unasylva 172: 3-12.

Roca Z (1998). Positive experiences in increasing the involvement of young men and women in rural development in Portugal. In: Increasing the involvement of young men and women in rural development in Europe. REU Technical Series 55. FAO regional office for Europe, Rome, Italy, pp. 39-61.

Saiti A, Mitrosili E (2005). Parental perception of the education of their adolescent children: evidence from Greek secondary education. Journal of Career and Technical Education 22: 9-30. [online] URL: http://scholar.lib.vt.edu/ejournals/ JCTE/v22n1/pdf/v22n1.pdf

Sakkas G (1980). The Greek workforce and the employment in the forest sector. The Forest 87 : 25-33. (In Greek)

Salminen S, Klen T, Ojanen K (1999). Risk taking and accident frequency among Finnish forest workers. Safety Science 33: 143-153. - doi: 10.1016/S0925-7535(99)00029-6

Siardos GK (1997). Methodology of social research in agriculture. Ziti Publications, Thessaloniki, Greece. (In Greek).

Slee B, Wiersum KF (2001). New opportunities for forest-related rural development. Forest Policy and Economics 3: 1- 4. - doi: 10.1016/ S1389-9341(01)00054-5

SPSS (1998). SPSS base applications guide. SPSS, Chicago, USA.

Theophile K (1996). Forests and employment. [online] URL: http://www.fao.org/docrep/ w2149e/w2149e09.htm\#forests\%20and $\% 20 \mathrm{em}$ ployment

Toupin D, LeBel L, Dubeau D, Imbeau D, Bouthillier L (2006). Measuring the productivity and physical workload of brushcutters within the context of a production-based pay system. Forest Policy and Economics 9: 1046-1055. - doi: 10.1016/j.forpol.2006.10.001

Tsioras PA (2004). Analysis and formation of modern forest workers training systems for the Greek forestry. PHD thesis. Aristotle University of Thessaloniki, Thessaloniki, Greece, pp. 231. (In Greek, with English abstract).

Vik T (1999). Improving working conditions in forestry - An example from Norway. In: Proceedings of the Joint FAO/ECE/ILO Committee of Forest Technology, Management and Training seminar on "Improving working conditions and increasing productivity in forestry", Banska Stiavniska (Slovakia) 9-13 September 1998. Forest Research Institute, Zvolen, Slovakia, pp. 51-65. 